\title{
Kepemimpinan Kepala Sekolah dalam Mengelola Sekolah Efektif
}

\author{
Asep Muljawan ${ }^{1}$ \\ asepmulyawan2014@gmail.com
}

\begin{abstract}
Leadership is ability, skills, guidance, motivate, supervise to influence the behavior of human as the goal. Although the leadership of principal related to the competency including hard skill or soft skill to give the affect human resources in order to achieve its objective and targets set.

The effective school has good management standards, transparent, responsible and accountable, empowers as important component including internal and external factor as achieve the vision - mission - goals of the school effectively and efficiently.

The leadership of the principal will give the strong affect to get effectively of school. Because it was related to the figure of principal in order to achieve the vision - missiongoals of the school.
\end{abstract}

Keyword: Leadership, Principal, effectively school

\section{Pendahuluan}

Pendidikan merupakan kunci kemajuan suatu bangsa. Tidak ada bangsa yang maju, yang tidak didukung pendidikan yang kuat. Pendidikan menjadi agen perubahan, aset penting dan jati diri suatu bangsa. Oleh karena itu setiap warga negara harus dan wajib mengikuti jenjang pendidikan, mulai dari pendidikan usia dini hingga pendidikan tinggi. Harapan warga negara berkualitas melalui pendidikan termaktub dalam UUD 1945 alinea ke-4 yang menyatakan salah satu tujuan bangsa Indonesia, yaitu mencerdaskan kehidupan bangsa. Bahkan, pemerintah berupaya meningkatkan taraf kehidupan rakyatnya dengan mewajibkan belajar pendidikan dasarnya selama 9 tahun bagi warga negara Indonesia.

Undang-Undang Republik Indonesia Nomor 20 Tahun 2003 tentang Sistem Pendidikan Nasional, menyatakan bahwa Pendidikan nasional bertujuan untuk mengembangkan potensi peserta didik agar menjadi manusia yang beriman dan bertakwa

\footnotetext{
${ }^{1}$ Dosen Tetap Prodi PAI STAI Asy-Syukriyyah
} 


\section{Jurnal Asy-Syukriyyah}

kepada Tuhan Yang Maha Esa, berakhlak mulia, berilmu, cakap, kreatif, mandiri, dan menjadi warga negara yang demokratis serta bertanggung jawab. ${ }^{2}$ Tujuan pendidikan ini mengandung pesan bahwa dalam proses pendidikan bukan hanya mencapai kuantitatif (nilai akademik) melainkan kualitatif atau kedalaman dan intensitas proses serta produknya. Tujuan mulia ini dalam pencapaiannya melalui proses pendidikan yang bermutu.

Kualitas atau mutu pendidikan di Indonesia dapat dilihat dari laporan Badan Program Pembangunan di bawah PBB (United Nations Development Programme/UNDP) tahun 2016, bahwa IPM Indonesia tahun 2015 berada di peringkat 113 dari 188 negara di dunia, turun dari posisi 110 di $2014 .^{3}$ Kondisi ini menuntut para pakar, pemerhati dan praktisi pendidikan untuk menyumbangkan pemikirannya guna memperbaiki mutu dan memajukan pendidikan. Salah satu upaya meningkatkan mutu atau kualitas pendidikan adalah efektifitas sekolah melalui kepemimpinan kepala sekolah. Hal ini dapat dimengerti karena kepemimpinan bukan hanya mengambil inisiatif, melainkan bermakna pula kemampuan mengatur dan menempatkan sesuatu sesuai dengan tempatnya. Efektifitas sekolah yang rendah, ditandai dengan kurang mantapnya perencanaan sekolah, minimnya pengorganisasian kegiatan sekolah dan pelaksanaan tidak sesuai rencana bahkan tanpa rencana.

Efektifitas sekolah menunjukan adanya proses perekayasaan dan pemberdayaan semua komponen sekolah dengan tujuan agar siswa belajar dan mencapai kompetensi yang telah ditetapkan. Sekolah akan efektif apabila kepala sekolah mampu menampilkan gaya kepemimpinan yang baik, berpengaruh langsung terhadap kinerja sekolah. Kinerja sekolah ditunjukkan oleh iklim kehidupan sekolah, budaya organisasi sekolah, etos kerja, semangat kerja guru, prestasi belajar siswa, disiplin warga sekolah secara keseluruhan. Dengan demikian, harapan atau tujuan pendidikan dapat terwujud ketika terdapat kepemimpinan kepala sekolah yang mumpuni dalam mengelola sekolah sehingga menjadi sekolah efektif.

\footnotetext{
${ }^{2}$ Undang-undang Republik Indonesia Nomor 20 Tahun 2003 tentang Sistem Pendidikan Nasional

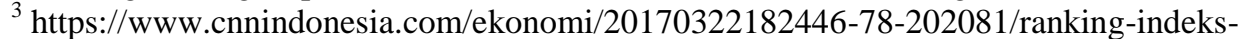
pembangunan-manusia-indonesia-turun-ke-113
} 


\section{Pengertian Sekolah Efektif}

Sekolah efektif dalam bahasa Inggris berasal dari dua kata, yaitu effective dan school. Makna efektif merujuk pada kemampuan menghasilkan sesuatu atau mampu mencapai tujuan. Efektivitas merupakan ukuran yang menyatakan sejauh mana sasaran atau tujuan (kualitas, kuantitas dan waktu) telah dicapai. Sekolah efektif memiliki pengertian yang berbeda dengan efektivitas sekolah. Beberapa definisi sekolah efektif akan dikemukakan di bawah ini ${ }^{4}$ :

ACT Council of P\&C Associations (2007) mendefinisikan sekolah efektif sebagai "those that successfully progress the learning and development of all of the students". Definisi diatas dapat dimaknai bahwa sekolah efektif adalah sekolah yang mampu meningkatkan belajar peserta didiknya dan mengembangkan semua siswa yang ada di sekolah tersebut secara sukses.

Sammons, Hilmans and Mortimore (1995: 3) mendefinisikan sekolah efektif sebagai: "one in which pupils progress further than might be expected from consideration of its intake. In other word an effective schools adds extra value to its students outcome in comparison with other schools serving similar intakes. By contrast an ineffective school is one in which students make less progress than expected given their characteristic at intake”. Definisi dari Sammons, Hilman dan Mortimore ini dapat dipahami bahwa sekolah efektif merupakan satu hal dimana kemajuan para siswa lebih baik dari kondisi yang biasa diharapkan. Atau sekolah efektif itu sekolah yang memberikan nilai lebih pada peserta didiknya dibandingkan sekolah lain yang memiliki karakteristik yang sama. Sedangkan Lawrenze W. Lezotte (1985) mendefinisikan sekolah efektif yaitu sekolah yang mampu memiliki dampak pembelajaran untuk mencapai semua misi, menunjukkan adanya kesamaan dalam mutu/kualitas.

Sekolah efektif adalah sekolah yang menjalankan fungsinya sebagai tempat belajar yang paling baik dengan menyediakan layanan pembelajaran yang bermutu bagi siswa siswinya. Pengertian umum sekolah efektif juga berkaitan dengan perumusan apa yang harus dikerjakan dengan apa yang telah dicapai. Sehingga suatu sekolah akan disebut efektif jika terdapat hubungan yang kuat antara apa yang telah dirumuskan untuk

\footnotetext{
${ }^{4}$ http://rukmant.blogspot.co.id/p/blog-page.html
} 


\section{Jurnal Asy-Syukriyyah}

dikerjakan dengan hasil-hasil yang dicapai oleh sekolah, sebaliknya sekolah dikatakan tidak efektif bila hubungan tersebut rendah. ${ }^{5}$

Taylor mendefinisikan sekolah efektif sebagai sekolah yang mengorgansiasikan dan memanfaatkan semua sumber daya yang dimilikinya untuk menjamin semua siswa (tanpa memandang ras, jenis kelamin maupun status sosial ekonomi) bisa mempelajari materi kurikulum yang esensial di sekolah ${ }^{6}$.

Berdasarkan beberapa definisi di atas dapat disimpulkan bahwa sekolah efektif merupakan sekolah yang mampu memberikan layanan KBM yang bermutu yang didukung oleh proses penyelenggaraan yang bermutu dan mampu menghasilkan lulusan yang bermutu. Dengan kata lain, Keberhasilan sebuah sekolah biasanya ditentukan oleh sejauh mana tujuan pendidikan itu dapat tercapai pada periode tertentu sesuai dengan lamanya pendidikan yang berlangsung di sekolah. Sekolah efektif mempunyai tingkat ketersesuaian yang tinggi antara apa yang telah dirumuskan untuk dikerjakan dengan hasil yang dicapai sekolah. Makna ini menunjukkan bahwa sekolah tidak dikategorikan sebagai efektif manakala peserta didiknya memiliki hasil yang bermutu dikarenakan kontribusi dari bimbingan belajar bukan dari proses yang dialami anak di sekolah.

Pengertian-pengertian sekolah efektif di atas mengandung makna esensi fungsi sekolah sebagai tempat belajar dimana sekolah efektif sangat diperlukan karena dalam konteks pendidikan tidak hanya menekankan pada pendekatan input-output secara makro tetapi yang lebih penting adalah persoalan proses input agar mendapat hasil yang memadai. Pendekatan input-output yang bersifat makro tersebut kurang memperhatikan aspek yang bersifat mikro yaitu proses yang terjadi di sekolah. Dengan kata lain, dalam membangun pendidikan, selain memakai pendekatan makro juga perlu memperhatikan pendekatan mikro yaitu dengan memberi fokus secara lebih luas pada institusi sekolah yang berkenaan dengan kondisi keseluruhan sekolah seperti iklim sekolah dan individu-individu yang terlibat di sekolah baik guru, siswa, dan kepala sekolah serta peranannya masing-masing dan hubungan yang terjadi satu sama lain. Input sekolah memang penting tetapi yang jauh lebih penting adalah bagaimana mendayagunakan input tersebut yang terkait dengan individu-individu di sekolah.

\footnotetext{
${ }^{5}$ Joni Ukat, Konsep Sekolah Efektif. 2008

${ }^{6}$ Taylor, B.O.,1990, Case Studies in Effective Schools Research. Kendal/Hunt Publishing Company
} 


\section{Ciri-ciri Sekolah Efektif}

Deskripsi berbagai teori mengenai sekolah efektif secara lebih terinci adalah sebagai berikut. Menurut Widodo ${ }^{7}$, sekolah efektif mempunyai ciri-ciri yaitu:

1. Adanya standar disiplin yang berlaku bagi semua warga sekolah

2. Memiliki suatu keteraturan dalam rutinitas kegiatan di kelas

3. Mempunyai standar prestasi sekolah yang sangat tinggi

4. Peserta didik mampu mencapai tujuan yang telah direncanakan

5. Peserta didik lulus dengan menguasai pengetahuan akademik

6. Adanya penghargaan bagi siswa yang berprestasi

7. Peserta didik mau bekerja keras dan bertanggung jawab

8. Kepala sekolah mempunyai program inservice, pengawasan, supervisi dan membuat rencana sekolah bersama-sama para guru

9. Adanya lingkungan yang nyaman

10. Penilaian yang secara rutin mengenai program yang dibuat siswa.

Menurut Mortimore yang dikutif oleh Supardi ${ }^{8}$, sekolah efektif dicirikan sebagai:

1. Sekolah memiliki visi dan misi yang jelas serta dijalankan dengan konsisten.

2. Lingkungan sekolah yang baik, dan adanya disiplin serta keteraturan di kalangan pelajar dan staf.

3. Kepemimpinan kepala sekolah yang kuat.

4. Penghargaan bagi guru dan staf serta siswa yang berprestasi.

5. Pendelegasian wewenang yang jelas

6. Dukungan masyarakat sekitar

7. Sekolah mempunyai rancangan program yang jelas .

8. Sekolah mempunyai fokus sistemnya tersendiri

9. Pelajar diberi tanggungjawab.

10. Guru menerapkan strategi-strategi pembelajaran inovatif

11. Evaluasi yang berkelanjutan.

12. Kurikulum sekolah yang terancang dan terintegrasi satu sama lain.

13. Melibatkan orangtua dan masyarakat dalam Pendidikan anak.

${ }^{7}$ Widodo, Suparno Eko. 2011. Manajemen Mutu Pendidikan: untuk Guru dan Kepala Sekolah, hal 34.

${ }^{8}$ Supardi, 2013. Sekolah Efektif, Konsep Dasar dan Praktiknya, hal 12. 


\section{Jurnal Asy-Syukriyyah}

Adapun Menurut Heneveld dalam Moerdiyanto ${ }^{9}$, faktor-faktor sekolah efektif adalah

1. Dukungan orang tua siswa dan lingkungan

2. Dukungan efektif dari sistem pendidikan

3. Dukungan materi yang cukup

4. Kepemimpinan yang efektif

5. Pengajaran yang baik

6. Fleksibilitas dan otonomi

7. Waktu yang cukup di sekolah

8. Harapan yang tinggi dari siswa

9. Sikap positif dari para guru

10. Peraturan dan disiplin

11. Kurikulum yang terorganisir

12. Adanya penghargaan dan insentif

13. Waktu pembelajaran yang cukup

14. Variasi strategi pembelajaran

15. Frekuensi pekerjaan rumah.

16. Adanya penilaian dan umpan balik

Dalam konsep standar nasional Pendidikan (SNP) maka sekolah efektif harus memenuhi standar-standar yang meliputi: (1) standar isi; memiliki kerangka dasar dan struktur kurikulum, beban belajar, KTSP, dan kalender akademik. (2) standar proses; proses pembelajaran dilaksanakan secara interaktif, menyenangkan, menantang, memotivasi peserta didik berpartisipasi aktif, memberikan ruang yang cukup bagi prakarsa, kreativitas dan kemandirian. (3) standar kompetensi lulusan; memiliki kecerdasan, pengetahuan, kepribadian, akhlak mulia, serta ketrampilan untuk hidup mandiri. (4) standar Tenaga Pendidik dan Kependidikan. (5) standar sarana dan prasarana. (6) Standar pengelolaan. (7) standar pembiayaan, dan (8) standar Penilaian.

Aan Komariah dan Cepi Triatna ${ }^{10}$ menilai dalam praktiknya bahwa ciri-ciri sekolah efektif adalah memiliki kriteria sebagai berikut;

\footnotetext{
${ }^{9}$ Moerdiyanto. 2007. Manajemen Sekolah Indonesia yang Efektif Melalui Penerapan Total Quality Management, hal 5.
} 
1. Siswa memiliki intelegensi yang normal, bahkan di atas rata-rata;

2. Siswa belajar dengan sungguh-sungguh, terbukti dengan selalu mengerjakan PR dan nilai ulangan tidak kurang dari 75 ;

3. Tingkat bolos siswa hanya $1 \%$, kecuali sakit dan ijin;

4. Siswa responsif terhadap kegiatan sekolah dan mengikuti kegiatan ekstrakurikuler berdasarkan minat dan bakatnya;

5. Organisasi siswa tidak sepi dari kegiatan;

6. Memperoleh berbagai penghargaan sehubungan dengan aktivitas siswa secara akademik maupun kegiatan hobi atau ekstrakurikuler;

7. Siswa berhubungan baik dengan guru dan personel lain secara empati;

8. Guru yang memiliki kelayakan dan memenuhi rasio sesuai jenis dan jenjang Pendidikan (misal : $1: 20$ untuk SMA);

9. Guru mengajar dengan antusias;

10. Guru mempersiapkan diri untuk mengajar;

11. Guru menguasai bahan pelajaran;

12. Guru melakukan penilaian terhadap belajar siswa;

13. Hasil penilaian siswa diperiksa dan dikomunikasikan kepada siswa ;

14. Guru mengakomodasi kesulitan belajar siswa;

15. Guru membina hubungan baik dengan siswa dan personel sekolah lainnya;

16. Guru terlibat dalam kegiatan ektrakurikuler atau akdemik;

17. Kepala sekolah memiliki visi untuk mengembangkan sekolah;

18. Fasilitas tersedia dengan cukup dan memadai;

\section{Kepemimpinan Kepala Sekolah}

Kepala sekolah mempunyai peranan yang penting dalam mengembangkan sekolah efektif melalui kepemimpinannya. Kepala sekolah sebagai pemimpin pendidikan di sekolah harus mampu mendayagunakan semua sumber yang ada di sekolah agar mencapai sekolah efektif. Kepala sekolah yang berhasil apabila mereka memahami keberadaan sekolah sebagai organisasi yang kompleks dan unik, serta mampu melaksanakan peranan

${ }^{10}$ Aan Komariah dan Cepi Triatna, Visionary Leadership Menuju Sekolah Efektif, 2008, hal 18-

19. 


\section{Jurnal Asy-Syukriyyah}

kepala sekolah sebagai seseorang yang diberi tanggung jawab untuk memimpin sekolah ${ }^{11}$. Studi keberhasilan kepala sekolah menunjukkan bahwa kepala sekolah adalah seseorang yang menentukan titik pusat dan irama suatu sekolah. Bahkan lebih jauh studi tersebut menyimpulkan bahwa "keberhasilan sekolah adalah keberhasilan kepala sekolah." Beberapa diantara kepala sekolah dilukiskan sebagai orang yang memiliki harapan tinggi bagi para staf dan para siswa, kepala sekolah adalah mereka yang banyak mengetahui tugas-tugas mereka dan mereka yang menentukan irama bagi sekolah mereka.

Berdasarkan rumusan hasil studi di atas menujukkan betapa penting peranan kepala sekolah dalam menggerakkan kehidupan sekolah dalam mencapai tujuan. Ada dua hal yang perlu diperhatikan dalam rumusan tersebut yaitu sebagai berikut: 1) kepala sekolah berperan sebagai kekuatan sentral yang menjadi kekuatan penggerak kehidupan sekolah; dan 2) kepala sekolah harus memahami tugas dan fungsi mereka demi keberhasilan sekolah, serta memiliki kepedulian kepada staf dan siswa.

Sesuai dengan ciri-ciri sekolah sebagai organisasi yang bersifat kompleks dan unik tugas dan fungsi kepala sekolah seharusnya dilihat dari berbagai sudut pandang. Dari sisi tersebut kepala sekolah dapat dipandang sebagai pejabat formal, sedang dari sisi lain seorang kepala sekolah dapat berperan sebagai manajer, sebagai pemimpin, sebagai pendidik dan yang tidak kalah penting seorang kepala sekolah juga berperan sebagai staf ${ }^{12}$.

Sebagaimana yang kita ketahui bahwasanya kepala sekolah berperan penting dalam mengejawantahkan visi pendidikan. Dalam hal ini, kepala sekolah memiliki pengaruh signifikan terhadap kualitas praktik pengajaran dan pencapaian belajar peserta didik di sekolah. Kepala sekolah melaksanakan fungsi kepemimpinan, yang melibatkan pendidik dan tenaga kependidikan lainnya, dalam rangka memetakan arah pendidikan sekolah di masa yang akan datang,mengembangkan pencapaian kualitas sekolah yang diharapkan, memelihara fokus perhatian terhadap proses pengajaran dan pembelajaran yang efektif, serta membangun lingkungan belajar yang kondusif untuk menghasilkan peserta didik yang unggul.

Kepemimpinan kepala sekolah menjadi faktor penentu dalam proses pendidikan yang berlangsung di sekolah. Kepemimpinan pendidikan memang bukan hanya diperankan oleh kepala sekolah. Peran besar pendidikan akan terwujud apabila ada kerjasama

\footnotetext{
${ }^{11}$ Wahjosumidjo, Kepemimpinan Kepala Sekolah, 2008, Hal 81.

12 Ibid, Halaman 82
} 
kepemimpinan di tiap tingkatan pengambil kebijakan (Menteri, Dirjen, Kepala Dinas dan stakeholders lainnya), sehingga dapat memfokuskan pada upaya bagaimana mencapai hasil belajar yang optimal bagi peserta didik. Untuk mendukung ke arah tersebut maka pemikiran tentang leadership matters, yaitu pemikiran mengenai peran dan kemampuan atau kapabilitas kepemimpinan kepala sekolah menjadi penting.

Dengan demikian sebagai seorang pemimpin dalam sebuah organisasi sekolah, kepala sekolah perlu menerapkan jiwa kepemimpinan agar tercapainya tujuan yang telah ditetapkan bersama. Kepala sekolah harus dapat mengetahui bagaimana pengertian kepemimpinan, bagaimana kepemimpinan kepala sekolah yang efektif serta indikatornya. Selain itu juga fungsi kepemimpinan kepala sekolah dalam meningkatkan organisasi sekolah menjadi sekolah yang efektif dan efisien serta dapat mencapai kesuksesan suatu sekolah.

Kepemimpinan merupakan aktivitas membujuk orang lain dalam suatu kelompok agar mau bekerja sama untuk mencapai tujuan bersama yang kegiatannya meliputi membimbing, mengarahkan, memotivasi, mengawasi tindakan atau tingkah laku orang lain ${ }^{13}$. Kepemimpinan adalah proses mempengaruhi, memerintah secara persuasif, memberi contoh, dan bimbingan kepada orang lain seperti guru, konselor, dan profesi kependidikan lainnya untuk mencapai tujuan yang telah ditetapkan ${ }^{14}$ Menurut Kartono kepemimpinan adalah kemampuan untuk memberikan pengaruh yang konstruktif kepada orang lain untuk melakukan suatu usaha kooperatif mencapai tujuan yang sudah direncanakan ${ }^{15}$.

Kepemimpinan kepala sekolah berkenaan dengan kemampuan dan kompetensi kepala sekolah, baik hard skilss maupun soft skills, untuk mempengaruhi seluruh sumber daya sekolah agar mampu mencapai tujuan dan sasaran yang telah ditetapkan sekolah. Kepemimpinan kepala sekolah yang efektif adalah kepemimpinan yang mampu memberdayakan seluruh potensi yang ada di sekolah dengan optimal, sehingga guru, staf, dan pegawai lainnya merasa ikut terlibat dalam pencapaian tujuan dan sasaran yang telah

${ }^{13}$ Uhar Saputra, Administrasi Pendidikan, Bandung : PT Refika Aditama, 2013, cet.2, Hal 128.

${ }^{14}$ Syaiful Sagala, Administrasi Pendidikan Kontemporer, Bandung : CV Alfabeta, 2013, cet.7, Hal 147.

${ }^{15}$ Euis Karwati \& Donni Juni Priansa, Kinerja dan Profesionalisme Kepala Sekolah Membangun Sekolah yang Bermutu, Bandung : CV Alfabeta, 2013, cet.1, Hal 163 
ditetapkan oleh sekolah, mampu memberikan kepuasan bagi para stakeholders sekolah, mampu memberikan inspirasi dan teladan yang baik bagi guru, staf, dan pegawai lainnya ${ }^{16}$.

Kepemimpinan kepala sekolah yang efektif antara lain dapat dianalisis berdasarkan kriteria berikut ini: (1) Mampu memberdayakan guru-guru untuk melaksanakan proses pembelajaran dengan baik, lancar dan produktif, (2) Dapat menyelesaikan tugas dan pekerjaan sesuai dengan waktu yang telah ditetapkan, (3) Mampu menjalin hubungan harmonis dengan masyarakat sehingga dapat melibatkan mereka secara aktif dalam rangka mewujudkan tujuan sekolah dan Pendidikan, (4) Berhasil menerapkan prinsip kepemimpinan yang sesuai dengan tingkat kedewasaan guru dan pegawai lain di sekolah, (5) Bekerja dengan tim manajemen, (6) Berhasil mewujudkan tujuan sekolah secara produktif sesuai dengan ketentuan yang telah ditetapkan ${ }^{17}$

Menurut Anwar ${ }^{18}$ kepala sekolah efektif dapat dilihat dari indikator-indikator kinerjanya yaitu: (1) Mewujudkan proses pembelajaran yang efektif, (2) Menerapkan sistem evaluasi yang efektif dan melakukan perbaikan secara berkelanjutan, (3) Melakukan refleksi diri ke arah pembentukan karakter kepemimpinan sekolah yang kuat, (4). Melaksanakan pengembangan staf yang kompeten dan berdedikasi tinggi, (5) Menumbuhkan sikap responsif dan antisipatif terhadap kebutuhan, (6). Menciptakan lingkungan sekolah yang aman dan tertib (Safe and Orderly), (7) Menumbuhkan budaya mutu di lingkungan sekolah, (8) Menumbuhkan harapan prestasi tinggi, (9) Menumbuhkan kemauan untuk berubah, (10) Melaksanakan Keterbukaan/Transparan Managemen Sekolah, (11) Menetapkan secara jelas mewujudkan Visi dan Misi, (12) Melaksanakan pengelolaan tenaga kependidikan secara efektif, (13) Melaksanakan pengelolaan sumber belajar secara efektif, (14) Melaksanakan pengelolaan kegiatan kesiswaan/ Ekstrakurikuler secara efektif.

Setelah kepala sekolah memahami pengertian kepemimpinan, kriteria dan indikator-indikator kinerjanya maka kepala sekolah juga mesti memahami tentang model kepemimpinan kepala sekolah ideal. Bahwa model ini berkaitan dengan pola kepemimpinan kepala sekolah yang tidak sekedar melaksanakan tugas rutin yang sama saja

\footnotetext{
${ }^{16}$ Ibid, hal 164

${ }^{17}$ M. Daryanto, Administrasi dan Manajemen Sekolah, Jakarta : PT Rineka Cipta, 2013, Hal 112

${ }^{18}$ Anwar, Qomari. 2011. Sekolah yang Efektif, (Online), hal 10
}

(http://ngatimin.weebly.com/uploads/5/4/1/1/5411453/sekolah_efektif.ppt, diakses 13 April 2012) 


\section{Jurnal Asy-Syukriyyah}

dari hari ke hari berikutnya. Semua sudah ditentukan standar kinerjanya dengan ciri-ciri : (1) Fokus pada kelompok, (2) Melimpahkan wewenang, (3) Merangsang kreativitas, (4) Memberi semangat dan motivasi, (5) Memikirkan program penyertaan Bersama, (6) kreatif dan proaktif, (7) memperhatikan sumber daya manusia, (8) membicarakan persaingan, (9) membangun karakter budaya dan iklim organisasi, (10) Kepemimpinan yang tersebar, (11) Bekerja sama dengan masyarakat.

\section{Penutup}

Kepemimpinan kepala sekolah yang mampu mengarahkan, memotivasi, membimbing, serta mengawasi guru, staf, peserta didik, dan seluruh warga sekolah kemudian menerapkan indikator-indikator kepemimpinan dan kriteria kepala sekolah serta memahami model kepemimpinan kepala sekolah maka dapat mewujudkan sekolah secara efektif dan efisien. 


\section{Jurnal Asy-Syukriyyah}

\section{DAFTAR PUSTAKA}

Anwar, Qomari. 2011. Sekolah yang Efektif, (Online), (http://ngatimin.weebly.com/uploads/5/4/1/1/5411453/sekolah_efektif.ppt, diakses 13 April 2012)

Aan Komariah dan Cepi Triatna, 2008, Visionary Leadership Menuju Sekolah Efektif, Jakarta: PT Bumi Aksara.

Euis Karwati \& Donni Juni Priansa, 2013, Kinerja dan Profesionalisme Kepala Sekolah Membangun Sekolah yang Bermutu, Bandung : CV Alfabeta.

Joni Ukat, 2008, Konsep Sekolah Efektif.

M. Daryanto, 2013. Administrasi dan Manajemen Sekolah, Jakarta : PT Rineka Cipta. Moerdiyanto. 2007. Manajemen Sekolah Indonesia yang Efektif Melalui Penerapan Total Quality Management. Makalah dalam seminar IMEC Penang-Malaysia, tanggal 22-24 Juni 2007.

Suharsaputra, Uhar. 2013. Administrasi Pendidikan. Bandung: PT Refika Aditama.

Supardi, 2013. Sekolah Efektif, Konsep Dasar dan Praktiknya, Jakarta: PT Raja Grafindo Persada.

Syaiful Sagala, 2013. Administrasi Pendidikan Kontemporer, cetakan ketujuh, Bandung : CV Alfabeta.

Taylor, B.O.,1990, Case Studies in Effective Schools Research. Kendal/Hunt Publishing Company.

Uhar Saputra, Administrasi Pendidikan, 2013. cetakan kedua, Bandung : PT Refika Aditama.

Undang-undang Republik Indonesia Nomor 20 Tahun 2003 tentang Sistem Pendidikan Nasional.

Wahjosumidjo, 2003. Kepemimpinan Kepala Sekolah Tinjauan Teoritik dan Permasalahannya, Jakarta: PT Raja Grafindo Persada.

Widodo, Suparno Eko. 2011. Manajemen Mutu Pendidikan: untuk Guru dan Kepala Sekolah, Jakarta: PT. Ardadizya Jaya.

https://www.cnnindonesia.com/ekonomi/20170322182446-78-202081/ranking-indekspembangunan-manusia-indonesia-turun-ke-113.

http://rukmant.blogspot.co.id/p/blog-page.html. 